\title{
Byproduct Mineral Commodities Used for the Production of Photovoltaic Cells
}

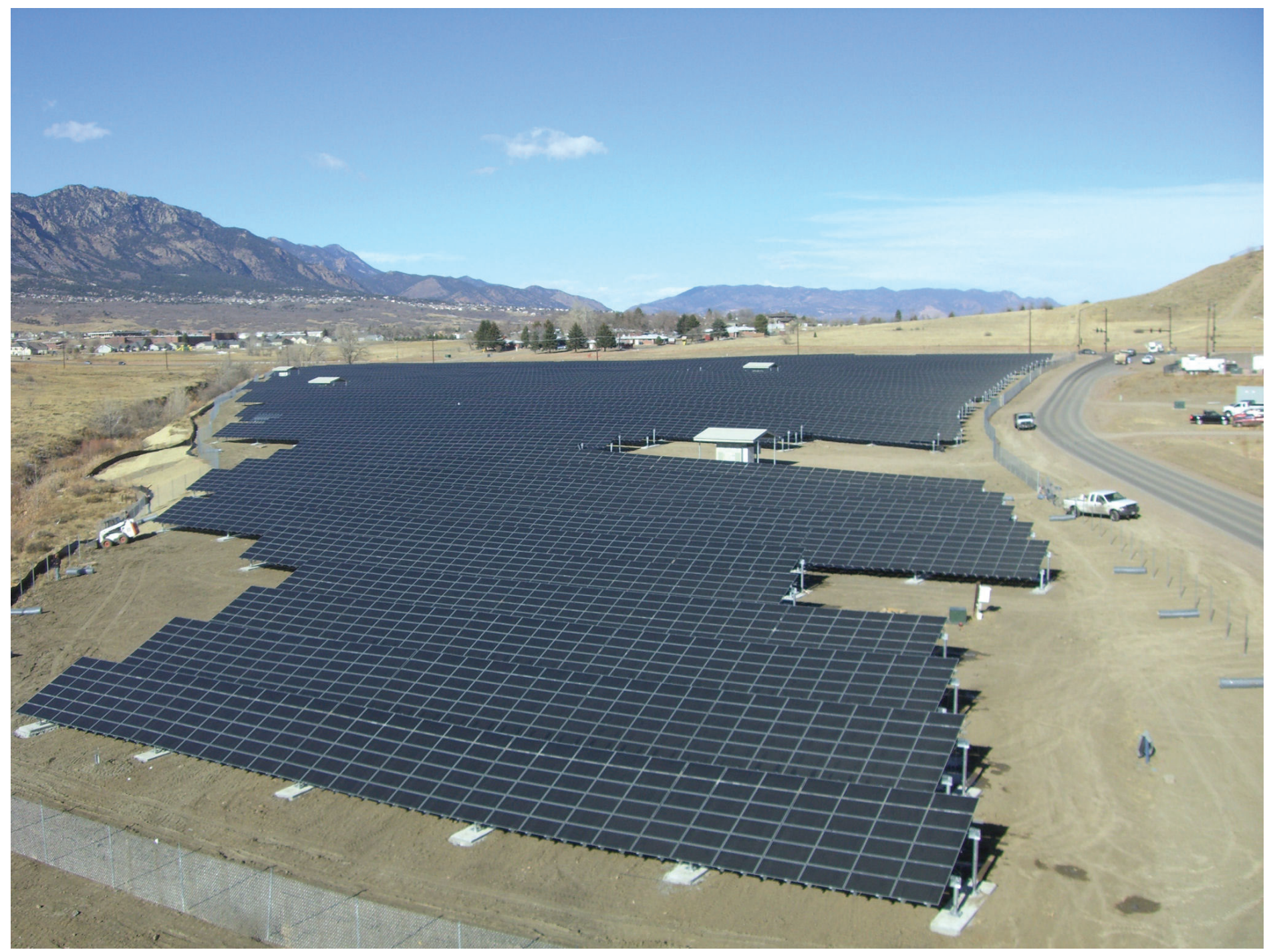

Circular 1365 
Front cover: A 2-megawatt, ground mounted solar photovoltaic array occupies the site of a former landfill at Fort Carson, Colo. Covering nearly 12 acres, the solar photovoltaic array is the largest array located on a U.S. Army facility. Photograph from the U.S. Department of Energy Western Area Power Administration (http://www.wapa.gov/newsroom/NewsFeatures/ftcarsonsolar.htm).

Back cover: Installation of flexible thin-film solar panels designed for use on commercial buildings. The panels are made out of thin-film solar cells from a combination of copper, indium, gallium, and selenium. Photograph courtesy of SoloPower, Inc., used with permission. 


\section{Byproduct Mineral Commodities Used for the Production of Photovoltaic Cells}

By Donald I. Bleiwas

Circular 1365

U.S. Department of the Interior

U.S. Geological Survey 


\section{U.S. Department of the Interior \\ KEN SALAZAR, Secretary \\ U.S. Geological Survey \\ Marcia K. McNutt, Director}

U.S. Geological Survey, Reston, Virginia: 2010

For more information on the USGS - the Federal source for science about the Earth, its natural and living resources, natural hazards, and the environment—visit http://www.usgs.gov or call 1-888-ASK-USGS

For an overview of USGS information products, including maps, imagery, and publications, visit http://www.usgs.gov/pubprod

To order this and other USGS information products, visit http://store.usgs.gov

Any use of trade, product, or firm names is for descriptive purposes only and does not imply endorsement by the U.S. Government.

Although this report is in the public domain, permission must be secured from the individual copyright owners to reproduce any copyrighted materials contained within this report. 


\section{Contents}

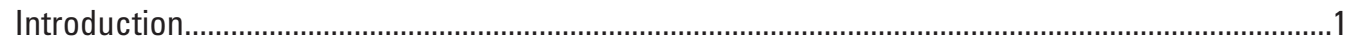

Sources and Supplies of Commodities Used in Photovoltaic Cells.................................................

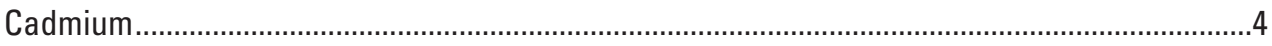

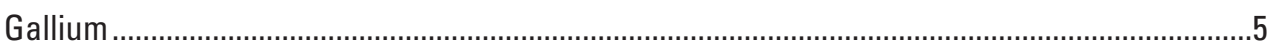

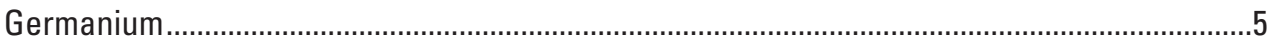

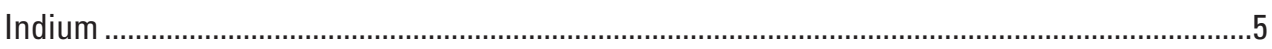

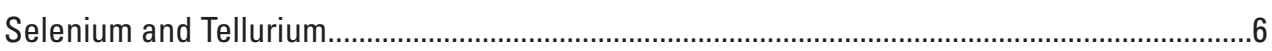

Amounts of Selected Mineral Materials Required for Generating One Gigawatt of Electricity ......6

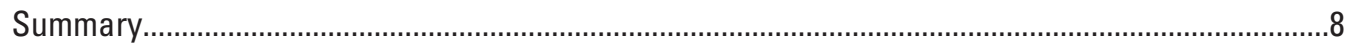

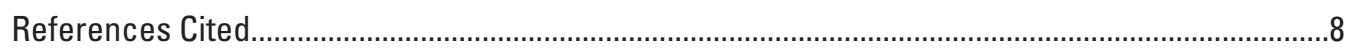

\section{Figures}

1. Diagram showing the structure of an electricity-generating solar cell ............................2

2. Diagram illustrating byproduct commodities that affect the efficient operation of

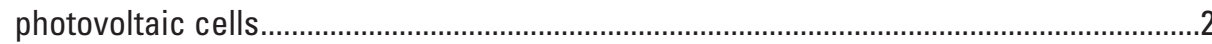

\section{Tables}

1. World production from primary sources and price of refined metals for byproduct commodities at yearend 2008

2. Metals required to produce thin-film photovoltaic cells with effective annual capacity of 8,760 gigawatthours

\section{Conversion Factors}

\begin{tabular}{|c|c|c|}
\hline Multiply & By & To obtain \\
\hline \multicolumn{3}{|c|}{ Mass } \\
\hline kilogram $(\mathrm{kg})$ & 2.205 & pound avoirdupois (lb) \\
\hline
\end{tabular}





\title{
Byproduct Mineral Commodities Used for the Production of Photovoltaic Cells
}

\author{
By Donald I. Bleiwas
}

\section{Introduction}

Rising fossil fuel costs, environmental concerns relating to global climate change, and Government policy to significantly increase our Nation's energy independence have placed greater emphasis on the generation of electricity from renewable sources, such as the Sun (light and heat), water, and wind, which for all intents and purposes are inexhaustible resources.

Although the total amount of electricity generated from the direct conversion of sunlight through photovoltaic cells is relatively small compared with that from other forms of renewable energy, the rate of growth in the sector is significant. The total value of energy of photovoltaic cells produced worldwide increased to nearly 7 gigawatts (GW) in 2008 from 45 megawatts (MW) in 1990, a compound annual growth rate of about 30 percent. In the United States, manufacturing of photovoltaic cells has grown exponentially to about $480 \mathrm{MW}$ in 2008, accounting for 6 percent of world production, from less than $10 \mathrm{MW}$ of photovoltaic capacity in 1990 (Benner, 2007; U.S. Department of Energy, Energy Information Administration, 2010), a compound annual growth rate of approximately 23 percent. A production capacity of $1 \mathrm{GW}$ of electricity [or 8,760 gigawatthours ${ }^{1}(\mathrm{GWh})$ ] is equivalent to the annual electricity requirements for roughly 800,000 average households in the United States (U.S. Department of Energy, Energy Information Administration, 2010). This estimate does not include losses of electricity, such as during transmission through power lines.

Similarly, China has demonstrated dramatic growth in production. In 2004, China contributed about $100 \mathrm{MW}$ of photovoltaic cells, about 1 percent of the global total. By 2008, China's output had grown to $1.9 \mathrm{GW}$ of photovoltaic capacity, about 27 percent of global output (U.S. Department of Energy, Energy Information Administration, 2010), a compound annual growth rate of about 80 percent. Other major producers of photovoltaic cells in 2008 included Europe (27 percent of world production), Japan (18 percent), and Taiwan (12 percent) (U.S. Department of Energy, 2010).

It should be noted that the increase in production capacity as measured in megawatts was probably as much the result of

${ }^{1}$ The amount of power generated during the course of 1 year. the improved efficiency of photovoltaic cells as the increase in demand for cells. The United States continued to be the leading electricity consuming nation in the world. The U.S. Department of Energy estimated that less than 0.02 percent of the total electricity generated in the United States in 2008 from all other renewable energy sources, including electric, wind, wood-burning, biomass, and geothermal sources, originated from photovoltaic arrays (U.S. Department of Energy, Energy Information Administration, 2010). The major reason for the low percentage was the high cost of producing electricity from photovoltaic cells compared with that from other established sources of electrical power. Wind, which is another renewable energy source often used as a comparison point against solar generation, produced 50 times the amount produced from solar sources (Blansett, 2007). For purposes of perspective, photovoltaic cells are about 7 to 17 percent efficient at converting sunlight to electricity, while electricity generated by fossil fuels (which produces about 70 percent of U.S. electricity generation) is about 28 percent efficient (U.S. Department of Energy, Energy Information Administration, 2008b).

Silicon-based photovoltaic cells currently dominate the market and are the type most often seen in solar installations and on rooftops. They account for more than 90 percent of the photovoltaic cells in use and can convert roughly 15 percent of the absorbed light to electricity in actual outdoor use. Research in recent years has resulted in increased efficiencies and lower production costs to the point where second-generation photovoltaic cells known as thin-film cells are making significant strides in penetrating the global commercial renewable energy market. The efficiency of these cells under laboratory conditions has ranged from about 20 percent to more than 40 percent, depending on composition and design (McMahon, 2008; Hecht, 2009; Novak and others, 2009).

Thin-film photovoltaic cells will likely become an important source of electricity generated from sunlight in the future. Most thin-film cells have some advantages compared with their thicker amorphous silicon cell counterparts (thick-film cells). Thin-film cells are lighter because they use much less material and can be flexible, making them adaptable to various designs in different applications. The cell's active area is usually only 1 to 10 micrometers $(\mu \mathrm{m})$ thick. Thick-film cells typically are as much as 200 to $400 \mu \mathrm{m}$ thick (SolarThinFilms, 2007). Thin-film cells are also more easily manufactured and 
therefore can be mass-manufactured by automated systems and are less expensive to produce. However, when compared with crystalline silicon cells, thin-film cells are generally less efficient at converting sunlight to electricity and may require up to twice as much space to produce the same amount of electricity. However, the gap is closing with significant progress on improving the output of electricity from thin-film cells being reported from laboratory research (U.S. Department of Energy, National Renewable Energy Laboratory, 2008). Figure 1 is a generalized figure of the components that comprise a photovoltaic solar cell.

The construction and operation of facilities required for the production of electricity generated by "capturing" sunlight, specifically photovoltaic cells, require a diverse mix of mineral materials. Photovoltaic cell-based powerplants use significant tonnages of mineral materials commonly used for structural support and transmission of electricity, including aluminum, concrete, copper, glass, nickel, steel, and zinc. Land-based reserves and resources (as opposed to resources on the sea floor) that contain these materials are widely distributed over a large portion of the Earth's crust, and any supply shortages would likely be short lived when given favorable market factors. Silica, the principal raw material used for manufacturing the cells, is abundant and readily available, as is copper, another major component in some types of cells. However, some of the mineral materials currently used in more advanced thin-film photovoltaic cells incorporate some less common mineral materials that are highly valued for the special properties they impart when combined with other mineral materials. These characteristics include durability and higher levels of light absorption and conversion to electricity (Mah, 1998). These mineral materials include cadmium, gallium, germanium, indium, selenium, and tellurium (fig. 2).

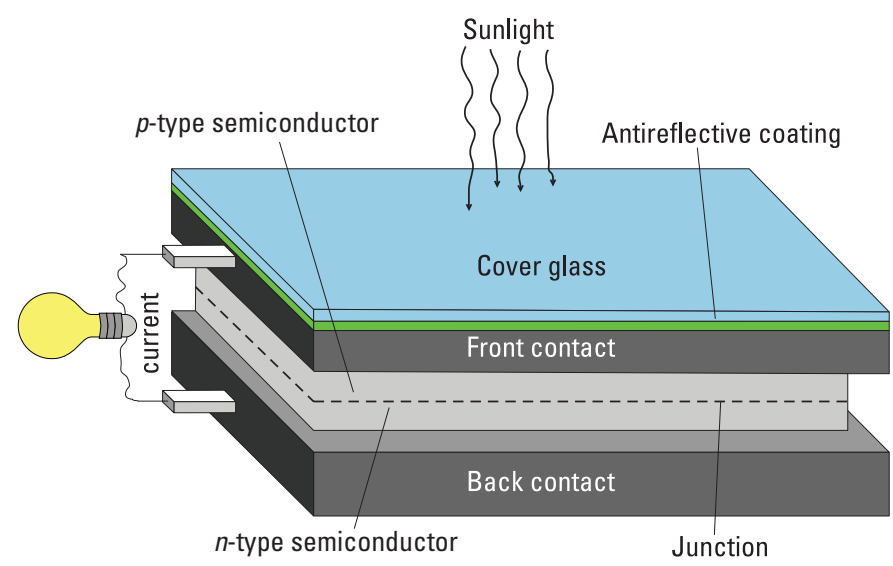

Figure 1. A generalized diagram showing the structure of an electricity-generating solar (photovoltaic) cell. Semiconductor films contain such metals as cadmium, gallium, germanium, indium, selenium, and tellurium. The $p$ layer generates a positive charge and the $n$ layer generates a negative charge. Front and back contacts made up of conductive metals and alloys containing aluminum, copper, gold, molybdenum, and silver. Diagram courtesy of California Energy Commission, used with permission.
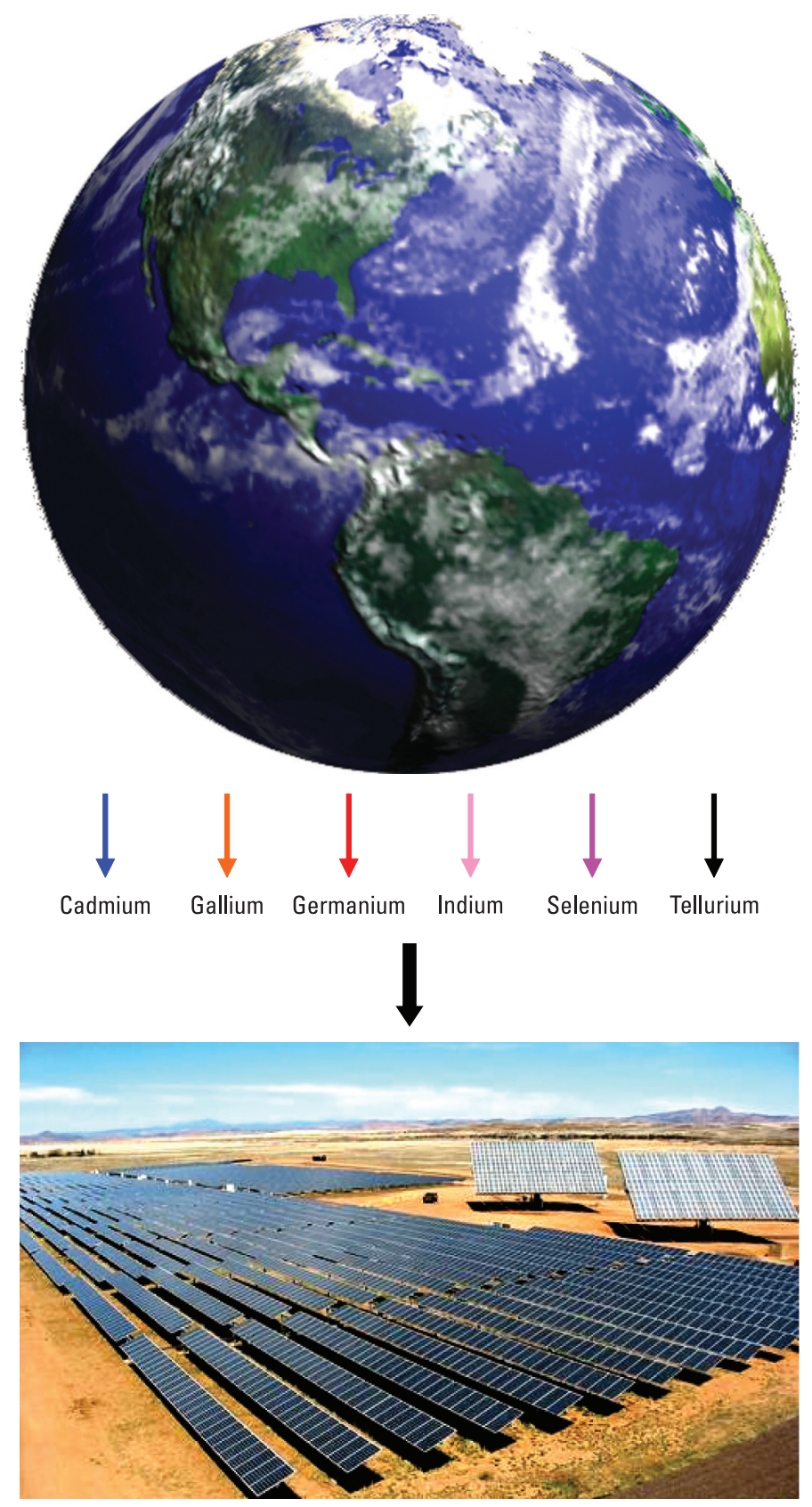

Figure 2. Metals such as cadmium, gallium, germanium, indium, selenium, and tellurium are recovered as byproducts from the production of other metals and are critical to varying extents for the efficient operation of photovoltaic cells. The current and future supply of some of these metals relies on ores mined in many countries and processed to refined metals in other countries as well as, to varying degrees, on the recovery of the metals as a byproduct of processing primary mineral commodities, fly ash produced from coal, and from recycling. Photograph of the Earth by the National Aeronautics and Space Administration (http://svs.gsfc.nasa.gov/vis/a000000/a000100/ a000155/); phorograph of solar farm by U.S. Department of Energy, National Renewable Energy Laboratory (http://www.nrel.gov/data/ pix/Jpegs/13338.jpg). 
Some examples of the use of these highly valued elements in thin-film photovoltaic cells include copper-indiumgallium-selenide alloy (CIGS), cadmium-tellurium (CdTe), and germanium used alone or in combination with other elements in the $p$-type (positive type) and $n$-type (negative type) silicon-based semiconductors in thin-film photovoltaic cells (fig. 1). Although these mineral commodities are used in relatively small amounts compared with other materials used in the manufacture of photovoltaic cells, they play a critical role in the performance of thin-film photovoltaic cells. With the increasing importance of photovoltaic systems as a source of supplying electricity for homes, industrial facilities, and supplemental grids in the United States and other countries, the demand for these mineral commodities will likely increase over the near term. The use of these mineral materials for other high-tech applications will also likely increase. There are concerns that the availability of mineral materials could restrain the rate of growth and the size of the industries that use these metals; however, estimates of reserves are temporal and expand and contract based on the cost of recovery and value (Wilburn and others, 2005).

This report describes the production and sources of several mineral commodities contained in thin-film photovoltaic cells that are not widely produced or are produced in relatively small quantities as well as general estimates of the amounts of the metals required to produce $1 \mathrm{GW}$. This report does not address the geographic distribution and supply of components used in the photovoltaic systems that rely on the availability of these metals. Investigation into methods of recovering materials contained in obsolete photovoltaic cells is a relatively new area of research that will likely become commercially established as the number of cells available for recycling increase. Recycling of these mineral materials is already supplementing supply from mining operations $(5 \mathrm{~N}$ Plus, 2010).

\section{Sources and Supplies of Commodities Used in Photovoltaic Cells}

The adequacy of the supply of cadmium, gallium, germanium, indium, selenium, and tellurium, all of which are produced as byproducts from the production of other metals, is critically important for the implementation of large-scale global photovoltaic systems using current technologies. The supply of these commodities relies to a great extent on mining ores for the production of aluminum, coal, copper, and zinc. Considering historical prices, it would be unlikely that production of the primary products would increase in order to produce more of the six metals discussed in this report. For example, it is unlikely that more coal will be mined and burned in order to recover more germanium from ash, nor is it likely that more copper ore would be extracted to recover tellurium and more bauxite mined to recover more gallium during the production of alumina.

Supplies for most of these byproduct metals recovered from mining could potentially be increased as a result of a number of separate and related scenarios, including:

- the supply of the primary revenue-producing commodities increases as a result of an increase in the value of the metals

- new government policies are created to provide incentives for production

- byproduct metal prices increase, justifying increased production from mines and processing plants that currently produce the metals (increased production can be attained from expansion of existing facilities and construction of new circuits to recover the metals from sites where the metals are not currently produced but are potentially recoverable)

- technologies of metallurgical recovery improve

- supplies from deposits not currently producing the metals discussed can be recovered, such as new deposits discovered, past producers, and treatment of residual mine and processing waste

- the byproduct commodities are substituted with other materials and

- recycling rates of the byproduct commodities improve

Additional production might also be generated from sources where cost is not the highest priority; for example, an enterprise may be willing to contract for a guaranteed supply of metals to ensure long-term availability or a facility that is vertically integrated is able to recover the higher costs for the metals in a value-added product, such as a photovoltaic cell.

Alternatively, an increase in the price of the metal commodity, perhaps coupled with concerns about the adequacy of supply for large-scale implementation of photovoltaic technology and applications and technologies competing for the same materials, could provide incentive to investigate substitution by other materials. This in turn could produce other technological advances [such as dematerialization (using less to provide the same or greater results)] that could result in a shift in demand to other commodities or using less material with the same or improved performance or some yet undiscovered technology. More efficient cells (achieving the same or more power for less cost) could result in changes in materials use. Sudden changes in material use patterns can also occur, such as wartime materiel production of scientific breakthroughs creating revolutionary changes in materials use.

Table 1 lists the estimated world refined primary production for each of the byproduct metals discussed in this report, the primary mining industry from which most of the byproducts are recovered, and the average price for the byproduct commodity. A brief discussion of each byproduct metal shown in table 1 follows. 
Table 1. World production from primary sources and price of refined metals for byproduct commodities at yearend 2008.

[e, estimated]

\begin{tabular}{|c|c|c|c|}
\hline $\begin{array}{l}\text { Byproduct com- } \\
\text { modity }\end{array}$ & $\begin{array}{c}\text { Primary' } \\
\text { commodities }\end{array}$ & $\begin{array}{c}\text { World refinery } \\
\text { production }^{\mathrm{e}} \\
\text { (in metric tons) }\end{array}$ & $\begin{array}{l}\text { Price of refined } \\
\text { metal } \\
\text { (in dollars per } \\
\text { kilogram) }\end{array}$ \\
\hline Cadmium & Zinc & 16,000 & 6 \\
\hline Gallium & Aluminum, zinc & 111 & 570 \\
\hline Germanium & Zinc, coal ${ }^{5}$ & 140 & ${ }^{6} \quad 1,490$ \\
\hline Indium & Zinc & $3 \quad 570$ & 685 \\
\hline Selenium & Copper & $3,7 \quad 3,000-3,500$ & 71 \\
\hline Tellurium & Copper & $450-500$ & 211 \\
\hline
\end{tabular}

${ }^{1}$ Derived as a product of mining ore for the purpose of extracting the listed commodity. Secondary production refers to the recovery of metals from the recycling of materials following useful service.

${ }^{2}$ Rounded to three significant figures. Data are from U.S. Geological Survey (2009a,b, 2010).

${ }^{3}$ Prices for cadmium, indium, selenium, and tellurium are averages for 2008. Prices for gallium and germanium, are yearend 2008. All prices rounded to the nearest dollar and are reported in dollars per kilogram. Data are from U.S. Geological Survey (2009a,b, 2010). Prices may vary based on numerous factors that include contractual agreements, size of inventories, and specifications of the metals traded.

${ }^{4} \mathrm{An}$ additional supply equal to about 25 percent of primary refined cadmium production (about 4,000 metric tons) originated from recycling.

${ }^{5}$ Recovered from fly ash, a byproduct of coal combustion for energy production.

${ }^{6}$ Price for polycrystalline zone-refined germanium; does not represent the unit value of entire world production. Data are from Guberman (2010).

${ }^{7}$ Does not include U.S. production.

\section{Cadmium}

Nearly all the world's primary (recovered from mining) cadmium is derived as a byproduct of processing sphalerite, a zinc sulfide ore containing varying amounts of cadmium, indium, lead, and other recoverable or potentially recoverable metals. Zinc ores containing cadmium are mined in many countries. The three leading producers of cadmium contained in ore in 2008, in descending order of quantity produced, were China, Peru, and Australia (Tolcin, 2010a).

Like many other commodities, the refined cadmium is smelted in countries other than the producing country. In 2008, the major producing countries of refined cadmium recovered from primary sources (and their approximated percentage shares of the world total) included China, where cadmium was refined from domestic and imported zinc concentrates (22 percent); the Republic of Korea, where virtually all cadmium was derived from imported zinc concentrates (15 percent); Japan, where cadmium was recovered from imported sources (11 percent); Kazakhstan, where cadmium was refined mostly from domestic sources (10 percent); and Canada, where cadmium was recovered from domestic, United States, and South American zinc concentrates ( 7 percent) (Tolcin, 2009a).
The United States has the capacity to recover primary cadmium from domestic zinc operations. In 2009, most of the Nation's zinc mines and refining facilities were on standby status because of low metal prices. Significant amounts of cadmium were not produced in 2008 owing to a reduction in zinc production worldwide. For example, cadmium production in the United States was about one-half the amount produced early in the decade. Although the actual amount is not known, a substantial amount (probably in the thousands of tons) of cadmium is not recovered worldwide and is contained in processing waste and disposed at impoundment areas because of the relatively low price of the metal.

Approximately 19,600 metric tons $(t)$ of refined primary cadmium was produced worldwide in 2008, of which about 20 percent, or roughly $4,000 \mathrm{t}$, was produced through recycling (Tolcin, 2009a, 2010a). Total refined production of cadmium from primary and secondary sources has remained relatively steady over the decade, although the share originating from primary cadmium has probably decreased (Wilburn, 2007). The decrease in supply from mining resulted primarily from an increase in the supply of secondary cadmium recovered from recycling of obsolete nickel-cadmium (NiCd) batteries coupled with decreased use of NiCd batteries because of technological advances in batteries that use other materials, such as lithium-ion and magnesium; primary cadium production has also decreased because of overall decreased demand for metals owing to depressed global economic conditions, and concerns associated with the metal's potentially toxic effects on the environment and human health.

Approximately 20 percent of the global supply of cadmium in 2008 originated from recycled $\mathrm{NiCd}$ batteries, with additional amounts supplied from other materials containing cadmium. In 2008, about 80 percent of global cadmium consumption was in NiCd batteries (Tolcin, 2009a). The supply of cadmium introduced from the recycling of obsolete consumer-type rechargeable NiCd batteries has been increasing and should continue to increase for some years because $\mathrm{NiCd}$ batteries for many consumer uses are still favored in low-cost consumer products. However, with improved battery technologies and concerns for the environment, the amount of cadmium used for the production of NiCd type batteries is declining (Wilburn, 2007). Industrial-sized NiCd batteries are widely used and may find application in storage for electricity produced by photovoltaic systems and from other renewable forms of energy production. This use could result in reversing a decline in NiCd-battery use in consumer products in the future. Although some environmental concerns have been raised regarding the use of cadmium in photovoltaic cells, it is unclear how these concerns might ultimately affect the use of the metal. However, the issue will likely result in placing more emphasis on ensuring recycling of photovoltaic cells.

Considering the important role that zinc plays in society and the supply of cadmium recovered through recycling, it is not anticipated that the metal will become unavailable for more than short durations. 


\section{Gallium}

Almost all the world's primary gallium supply originates as an impure byproduct recovered during the processing of bauxite ore to alumina, a precursor to refined aluminum. Minor amounts of gallium are also recovered from residues produced during the process to recover primary zinc metal. In 2008, approximately $111 \mathrm{t}$ of primary refined gallium was produced worldwide, about 30 percent below reported capacity (Jaskula, 2010). Some of the impure gallium product is refined onsite, but much of it is sold and processed into gallium metal of differing purities elsewhere. China, Germany, and Kazakhastan are the leading producers of impure gallium. They compose roughly 50 percent of world primary production. Other major producers, in decreasing order of quantity produced, include Japan and Russia. The leading purchasers and producers of refined gallium include China, Japan, and the United States.

The amount of potentially recoverable gallium is much larger than that actually recovered owing to limited demand for the metal. Most of the gallium contained in bauxite ore is actually disposed as waste from the processing of ore to alumina. An increase in gallium demand beyond current capacity can be easily satisfied with the addition or expansion of recovery circuits at existing alumina facilities. It is unlikely that the future supply of gallium will be constrained because of limited aluminum production. Very little gallium is recovered from recycled obsolete materials.

Gallium finds its greatest application in electronic circuitry, laser diodes, and light emitting diodes (LEDs) (Kelly and Matos, 2006; Matos, 2006). Photovoltaic cells that incorporate gallium arsenide are mostly used for generating electricity for satellites and space exploration. Although gallium arsenide is well suited to photovoltaic cells, its application for consumer use is greatly limited by the high cost of producing gallium arsenide crystals, a necessary component of the cell. Lowering the cost of production will likely be key to commericialization of the technology.

\section{Germanium}

Approximately $140 \mathrm{t}$ of primary germanium metal in various forms was produced in 2008, of which roughly 60 percent was recovered from residues generated during the production of refined zinc derived from ores, and about 30 percent originated from leaching fly ash, a waste product of coal combustion (David Guberman, mineral commodity specialist, U.S. Geological Survey, oral commun., April 19, 2010). The vast majority of germanium production originated from China (a mix of domestic and imported feedstock) and Canada (mostly North American in origin). Other countries with notable germanium production include Belgium (all derived from imported feedstock), Russia (mostly domestic in origin), and the United States (a mix of domestic and imported).

In 2007, germanium metal was in short supply owing to a reduction in zinc production, which was caused by low metal prices that resulted from depressed demand and increased demand for germanium for use in fiber optics and infrared technologies (Matos, 2006; Guberman, 2009, 2010). This supply shortage was reflected in the price of germanium, which increased by nearly 30 percent to $\$ 1,240$ per kilogram for zone-refined germanium at yearend 2007 from about $\$ 950$ per kilogram at the beginning of the year (Guberman, 2010). In 2008, the price of the metal continued to rise, and yearend 2008, was $\$ 1,490$ per kilogram. Primary germanium supply relies to some extent on zinc production, which is currently operating significantly below capacity. More germanium could potentially become available with the improvement of the zinc market. The amount of germanium potentially recoverable from coal fly ash is essentially unlimited (Simons and Prinz, 1973a), but the commercial recovery of the metal is not currently viable to the extent that it has replaced germanium recovered from primary sources. The amount of germanium recovered from recycling efforts is not a significant contributor to world supply of germanium.

\section{Indium}

Approximately $570 \mathrm{t}$ of indium was produced from primary sources in 2008 (Tolcin, 2010b). Most of the world's primary indium supply originates as a byproduct of processing zinc ores mined in China, Peru, and Australia (in decreasing order of quantity produced). Another source of primary indium supply is mines of other types of metals, mostly copper, lead, tin, and precious metals. As with many metals, the smelting and refining of concentrates take place in countries other than where the ore is mined. Like cadmium, most of the world's indium supply originates from zinc mining. The majority of smelting and refining of indium takes place in Canada, China, Japan, and the Republic of Korea. China recovers nearly 55 percent of the world's refined indium from mostly domestic sources. The Republic of Korea (mostly from imported concentrates), Japan (from imported concentrates), and Canada (from mostly domestic and U.S. sources) account for about 13,11 , and 8 percent of the world's primary refined indium production, respectively (Tolcin, 2009b, 2010b).

Flat-panel liquid crystal displays (LCDs) for computer monitors and flat-screen televisions are the leading application for indium (as an alloy consisting of indium tin oxide), consuming more than 50 percent of the world primary output of indium, and will likely continue to dominate the use of the element for the foreseeable future. Nearly all indium reclaimed from manufacturing of electronics, including LCDs, is also used for producing flat-panel displays (Matos, 2006; Mikolajczak, 2009). Photovoltaic cells and other competing uses may increase demand for indium. Expansions of existing recovery circuits and installations of new primary recovery circuits with improved recoveries are coming online, exploration of deposits containing anomalously high amounts of indium have become more attractive for potential development, and the recovery of indium from processing wastes (tailings and slags) is now being practiced on a limited scale and could become a 
significant source of future indium supply if demand justifies investment. More efficient production methods using indium tin oxide and improved technology to reclaim metals collected from the production of LCDs and other products are also being researched (Mikolajczak, 2009).

Although not currently a major source of indium, a potentially significant secondary indium industry with a focus on recycling electronic waste is likely to emerge under favorable market conditions and will potentially play a role in supplementing world indium supply as the metal finds use in other applications.

As with cadmium, the largest percentage of indium production relies on mining zinc ores. It is anticipated that the supply of indium will be able to meet anticipated industrial demand. Gallium may also potentially serve as a substitute for indium in some applications, including photovoltaic cells, if there are cost benefits (Andersson, 2000).

\section{Selenium and Tellurium}

In 2008, approximately 3,000 to $3,500 \mathrm{t}$ of refined selenium and 450 to $500 \mathrm{t}$ of refined tellurium were produced as a result of mining and processing ores derived from primary sources (George, 2009). Japan and Belgium are the leading producers of these metals, which are recovered from copper concentrates and residues purchased primarily from mining operations in Africa, Asia, Australia, and South America. China is also a large purchaser from these regions and also produces the metals from domestic mining operations. Although some of the selenium and tellurium metal is recovered from some gold and silver deposits with anomalously high levels of selenium and tellurium content, nearly all the world's selenium and tellurium metal produced from ore deposits depends on profitable recovery from residues (slimes) produced during the refining of copper to copper cathode; this copper cathode is derived from the mining of copper sulfide ore, from some polymetallic ore bodies (for example, the Sudbury nickel district), and from lead and zinc operations (Simons and Prinz, 1973b,c). The content of each selenium and tellurium metal in copper concentrate is generally below 100 parts per million each. The metals are commercially profitable to recover only when they are concentrated in residues collected from copper refineries and treated for the recovery of metals of value, which generally include antimony and precious metals, such as gold, palladium, platinum, and silver.

It was also estimated that, approximately 4,600 $\mathrm{t}$ could have been potentially recovered from copper anode slimes in 2008 (George, 2009). Mining operations that leach copper from ores do not produce anode slimes, and therefore none of the selenium or tellurium contained in the ores is recovered (Simons and Prinz, 1973b,c). Relatively small amounts of the two metals are also recovered from residues generated during the processes necessary to produce gold, lead, and zinc. Overall, roughly 50 to 60 percent of the selenium and tellurium contained in ore is refined to metal. The balance is contained in waste products, such as mill tailings, and in slag (Ojebuoboh, 2007). Because of expectations of increasing demand and higher prices for selenium metal, there is an increased focus on exploration for deposits containing selenium, which at one time was considered a deleterious component in ores, as well as tellurium. Significant improvements in recovery of selenium and tellurium at refineries will likely result in an increase in supply of selenium if prices justify recovery.

Using broad assumptions, a U.S. Department of Energy, National Renewable Energy Laboratory (2000) study estimated that approximately $900 \mathrm{t}$ of copper sulfide ore extracted from copper porphyry deposits, the largest source of world primary copper, is required to recover 1 pound of byproduct tellurium and that at least 1,000 $\mathrm{t}$ of byproduct tellurium, or roughly ten times the world production in 2008 , could potentially be produced annually from mining operations; however, for a number of reasons, chief among them being economics and proprietary technologies, the metal is not recovered at this time. This estimate is relatively close to the $1,200 \mathrm{t}$ of tellurium potentially recoverable from copper anode slimes (George, 2009). An earlier study stated that approximately 0.4 pound of tellurium was contained in 2,000 pounds of blister copper, of which approximately 43 percent of the metal was potentially recoverable (Simons and Prinz, 1973c). The difference in the estimated recoverable amounts in the studies can be attributed to technological advances that have resulted in significant improvements in metallurgical recoveries since the early study was published.

The high price of tellurium and the anticipated increased demand for the metal have brought attention to a number of mineral deposits found to contain high tellurium contents that are being considered for development in China and Mexico. As is also typical with sustained higher commodity prices and (or) anticipated increased demand, efforts are concentrated more on research for improved recoveries from ores and investigations into processing the waste materials generated by producing and past mines and processing plants for potential recovery of the metals. These activities will likely result in an increase in supply of the metals when prices justify their recovery.

Only small amounts of selenium and tellurium metal are recovered by recycling obsolete materials.

\section{Amounts of Selected Mineral Materials Required for Generating One Gigawatt of Electricity}

Table 2 provides rough estimates of the amounts of the six byproduct mineral materials used in two types of thin-film photovoltaic cells sufficient to produce $8,760 \mathrm{GWh}$ annually with a peak capacity of $4 \mathrm{GW}$ of electricity production and an effective average daily capacity of $1 \mathrm{GW}$, based on a 25 percent capacity factor, which accounts for the hours of daylight and other factors affecting electricity production. 
Depending on the type, efficiency of cells employed, and a number of other factors, a total surface area of roughly 40 square kilometers (nearly 15 square miles) of photovoltaic panels could be required to produce this amount of electricity assuming a peak wattage output of 110 watts per square meter. The area required to accommodate other necessary parts of generating plants is not included in this estimate. An area of roughly 33,000 square kilometers (13,000 square miles) might be required to meet the electricity needs of the United States using only photovoltaic cells (New Mexico Solar Energy Association, 1999). This is not to suggest that a single plant would be required to occupy this amount of area for the production of the electrical energy; rather it would likely require a significant number of plants distributed throughout the United States. For perspective, the largest operating photovoltaic plant in the world is the Parque Fotovoltaico Olmedilla de Alarcon solar farm in Spain which is designed to produce about $60 \mathrm{MW}$ at peak levels. In California, the proposed 550MW Topaz Solar Farm Project is planned to produce nearly 1.1 GWh using thin-film CdTe photovoltaic cells when it becomes fully operational in 2013 (Pacific Gas and Electric Company, 2008). If the plant's construction follows the original design, the plant will be the world's largest, encompassing an area of about 25 square kilometers (9.5 square miles) (Hudson, 2008; Rigley, 2009).

The estimates presented in table 2 provide a perspective for selected material requirements in three types of photovoltaic cells used mostly for commercial purposes. Other types of photovoltaic cells, such as gallium-arsenide- and germanium-based cells, are mainly reserved for use in satellites and space exploration because of their high efficiencies. They are much more expensive compared to most other types of cells in use and not economically practical for large-scale commercial application, but research is ongoing. The estimates in table 2 should be considered to be a "snapshot" because advances in the field of photovoltaic technology that require different amounts and types of materials are announced frequently. Actual material requirements could differ significantly from the estimates because cell types are generic categories and do not have a standardized composition. Within cell types, the amounts and selections of materials used and their structure vary. In addition, information about characteristics of cells is usually considered proprietary and therefore is difficult to acquire. The amount of electricity produced from photovoltaic cells of the same composition and type will differ in practice because of numerous criteria that include the design of the array (fixed-position or tracking), geographic location, including altitude and latitude (determines the number of hours and the angle of sunlight), and prevailing climatic conditions, primarily cloud cover during daylight hours. These factors result in an electricity production efficiency factor that can vary from 15 to 35 percent of production under optimum (peak) conditions. The calculations in table 2 use an assumed capacity factor of 25 percent (estimates range from about 20 to 30 percent for the 48 contiguous United States). For these reasons, material requirements and electrical power production are most often standardized under ideal circumstances and as peak power per panel or as electricity produced by photovoltaic panel surface area at peak power. A capacity factor is applied for planning and construction purposes.

Table 2. Metals required' to produce thin-film photovoltaic cells with effective annual capacity of 8,760 gigawatthours.

[CIGS, copper-indium-gallium-selenide alloy; e, estimated; XX, not applicable]

\begin{tabular}{|c|c|c|c|c|}
\hline \multirow[b]{2}{*}{ Type of photovoltaic technology } & \multicolumn{4}{|c|}{ Metals required } \\
\hline & Metal & $\begin{array}{c}\text { Quantity }{ }^{\mathrm{e}, 2} \\
\text { (metric tons) }\end{array}$ & $\begin{array}{l}\text { Percentage of } 2008 \text { estimated } \\
\text { world refinery production from } \\
\text { primary sources }^{3}\end{array}$ & $\begin{array}{l}\text { Value of contained metale,4 } \\
\text { (in millions of dollars) }\end{array}$ \\
\hline \multirow{3}{*}{ Thin-film CIGS } & Indium & 90 & 16 & 62 \\
\hline & Selenium & 180 & 6 & 13 \\
\hline & Total & $\mathrm{XX}$ & $\mathrm{XX}$ & 92 \\
\hline Thin-film cadmium telluride & Cadmium & 340 & 2 & 2 \\
\hline
\end{tabular}

${ }^{1}$ Metals required to produce photovoltaic cells that can generate 4 gigawatts (GW) of peak power or 8,760 gigawatthours per year (GWh/yr) of effective capacity. One GW is equivalent to 1 billion watts, 1,000 megawatts, and 1 million kilowatts of effective capacity of electricity production. Applying a 25 percent capacity factor, an installed peak capacity of approximately $4 \mathrm{GW}$ would be required to produce $1 \mathrm{GW}$ of electricity on an average daily basis or $8,760 \mathrm{GWh} / \mathrm{yr}$, electricity sufficient to meet the average annual need of 11,000 kilowatthours for 800,000 households in the United States (U.S. Department of Energy, Energy Information Administration, 2009a). No energy storage, such as batteries, was assumed.

\footnotetext{
${ }^{2}$ Calculation for metal requirements assumed to be linear and based on a 3-micrometer $(\mu \mathrm{m})$ thickness cell. Two- $\mu \mathrm{m}$ thickness cells are in development and are expected to penetrate the commercial market within the next several years. The combination, amounts, and efficiency of materials used in photovoltaic cells can vary; the amounts and combinations listed in this table are not representative of all technologies. Estimates for material requirements should be considered with caution. The amount of material required (the size of the array) to produce a given amount of energy can vary greatly by the physical location of photovoltaic arrays that affect insolation (such as latitude and weather conditions) and design factors (such as the type of cells and whether the system is fixed tilt or tracking). Estimates are based on a 25 percent capacity factor. Values are rounded to two significant figures.

${ }^{3}$ Rounded to two significant figures.

${ }^{4}$ Rounded to two significant figures. Prices for cadmium, indium, selenium, and tellurium are average 2008; prices for gallium and germanium are yearend 2008. All prices are rounded to the nearest dollar and are reported in dollars per kilogram. Data are from U.S. Geological Survey (2009a,b, 2010). Prices may vary based on numerous factors that include contractual agreements, size of inventories, and specifications of the metals traded.
} 


\section{Summary}

Metals such as cadmium, gallium, germanium, indium, selenium, and tellurium are important mineral materials used in current photovoltaic cell technology. Most of the world's primary supply of these mineral commodities is recovered as byproducts from ores processed mainly for the purpose of producing aluminum, copper, lead, and zinc and, in the case of germanium, from ash derived from burning coal for the production of energy. In some cases, the refined metals originate in the countries in which they are mined, while in other cases, intermediate products containing the metals and refined metals are recovered by processers located in other countries. Assuming that the modest rate of market penetration of electricity from photovoltaic cells and competing markets increases demand for cadmium, gallium, and germanium, the resulting new demand can be met in relatively quick order with the expansion of existing recovery circuits or the addition of new circuits. It is very unlikely that, under most scenarios, the need would arise to mine more bauxite, copper, and zinc ore or to burn more coal to satisfy anticipated material requirements to meet the photovoltaic-generated demand for these mineral materials. For other metals, such as indium, selenium, and tellurium, targeted mineral exploration and improvements in metallurgical recoveries are likely to be needed to meet demand requirements. Substitution for these materials in nonphotovoltaic applications could also "free up" supply. Conversely, however, other new applications can produce supply constraints or increase metal prices and place pressure on their use in photovoltaic technology.

The supply of these metals from secondary sources will likely increase over time when photovoltaic cells are recycled as a result of breakage or when they reach the end of their useful life of approximately 20 to perhaps 30 years (U.S. Department of Energy, Solar Technologies Program, 2008a).

Other than perhaps short term interruptions resulting from market forces or geopolitical events, it is not anticipated that there will be any long term material constraints that would prevent the development of a significant amount of energy from photoelectric cells. Reserve estimates are not static; although a particular metal might be considered rare and scarce, if a profit can be made from its recovery, then there will likely be no long-term shortage. Technological advancements driven by the desire to produce energy at a lower cost will likely result in increases in efficiency requiring smaller amounts of these metals per unit of energy produced, substitution with other materials, and other advancements in science.

\section{References Cited}

5N Plus, 2010, 5N Plus-Pure and simple: 5N Plus, accessed April 7, 2010, at http://www.5nplus.com/index.php/en/.
Andersson, B.A., 2000, Materials availability for largescale thin-film photovoltaics; Progress in photovoltaics: Research and Applications, v. 8, no. 1, p. 61-76, accessed May 7, 2009, at http://www3.interscience.wiley.com/ journal/70001629/abstract.

Benner, John, 2007, Materials demand for the rapidly expanding solar electricity industry: U.S. Department of Energy, National Renewable Energy Laboratory, March 7, accessed May 5, 2009, at http://cdnintlminerals.com/i/ pdf/3Party/2007-03-07_NREL.pdf.

Blansett, Christopher, 2007, Solar energy; Solar finance and forecast conference: J.P. Morgan, accessed May 15, 2009 at http://www.jpmorgan.com/cm/Satellite?blobcol=urldata\&b lobheader $=$ application $\% 2 F p d f \&$ blobkey $=i d \&$ blobtable $=M$ ungoBlobs\&blobwhere $=1158480318554 \&$ ssbinary $=$ true $\& b$ lobheadername $1=$ Content-disposition $\&$ blobheadervalue $1=$ attachment;filename=Solar_Energy:_Solar_Finance_and_ Forecast_Conference.pdf.

George, M.W., 2009, Selenium and tellurium, in Metals and minerals: U.S. Geological Survey Minerals Yearbook 2008, v. I, p. 65.1-65.9, accessed May 15, 2009, at http://minerals.usgs.gov/minerals/pubs/commodity/ selenium/myb1-2008-selen.pdf.

Guberman, D.E., 2009, Germanium, in Metals and minerals: U.S. Geological Survey Minerals Yearbook 2008, v. I, p. 30.1-30.7, accessed May 15, 2009, at http://minerals.usgs.gov/minerals/pubs/commodity/ germanium/myb1-2008-germa.pdf.

Guberman, D.E., 2010, Germanium, in U.S. Geological Survey Mineral Commodity Summaries 2010: U.S. Geological Survey, p. 64-65, accessed June 7, 2010, at http://minerals.usgs.gov/minerals/pubs/mcs/.

Hecht, Jeff, 2009, Photonic frontiers - Thin-film photovoltaicsThe key to success is higher efficiency: OptoIQ, v. 45, no. 3 , March 1, accessed June 5, 2009, at http://www.optoiq.com/ index/display/article-display.articles.optoiq2.photonicstechnologies.applications-__markets.energy__environment. solar-_ photovoltaics.2009.12.photonic-frontiers-thinfilm-photovoltaics-the-key-to-success-is-higher-efficiency. QP129867.dcmp $=$ rss.page $=1 . \mathrm{html}$.

Hudson, Gavin, 2008, World's 13 biggest solar energy plants, photovoltaic: Ecolocalizer, March 5, accessed February 24, 2009, at http://ecoworldly.com/2008/03/05/ worlds-7-biggest-solar-energy-plants/.

Jaskula, B.W., 2010, Gallium, in U.S. Geological Survey Mineral Commodity Summaries 2010: U.S. Geological Survey, p. 58-59, accessed June 7, 2010, at http://minerals.usgs.gov/minerals/pubs/mcs/. 
Kelly, T.D., and Matos, G.R., 2006, Historical statistics for mineral and material commodities in the United States: U.S. Geological Survey Data Series 140, accessed April 12, 2010, at http://minerals.usgs.gov/ds/2005/140/.

Mah, Olivia, 1998, Fundamentals of photovoltaic materials: National Solar Power Research Institute, Inc., 10 p., accessed May 8, 2009 at http://userwww.sfsu.edu/ ciotola/ solar/pv.pdf.

Mikolajczak, Claire, 2009, Availability of indium and gallium-September 2009: Indium Corporation, 10 p., accessed April 8, 2010, at http://www.indium.com/_dynamo/ download.php?docid $=552$.

Matos, G.R., 2006, Effects of regulation and technology on end uses of nonfuel mineral commodities in the United States: U.S. Geological Survey Scientific Investigations Report 2006-5194, accessed April 12, 2010, at http://pubs.usgs.gov/sir/2006/5194/.

McMahon, Síle, 2008, NREL boosts CIGS thin-film efficiency to record 19.9 percent: Semiconductor Media Limited PV-tech.org, March 25, accessed June 5, 2009, at http://www.pv-tech.org/news/_a/nrel_boosts_cigs_thin_ film_solar_cell_efficiency_to_record_199_percent/.

New Mexico Solar Energy Association, 1999, The solar resource: New Mexico Solar Energy Association, accessed May 7, 2009, at http://joewerne.com/eos/text/nmsea.html.

Novak, Erik, Hopkins, Stephen, and Masters, Andrew, 2009, Optical surface profiling-3-D surface characterization improves solar cell efficiency: OptoIQ, December 23, accessed January 4, 2010, at http://www.optoiq.com/index/photonics-technologiesapplications/lfw-display/lfw-article-display/371939/articles/ optoiq2/photonics-technologies/applications-_markets/ energy__environment/solar___photovoltaics/2009/12/ optical-surface-profiling-3-d-surface-characterizationimproves-solar-cell-efficiency.html.

Ojebuoboh, Funsho, 2007, Selenium and tellurium from copper refinery slimes and their changing applications: European Metallurgical Conference, June 11-14, 2007, Düsseldorf, Germany, Proceedings, v. 1, p. 571-585, accessed May 5, 2009, at http://www.emc.gdmb.de/2007/ proceedings2007cont.pdf.

Pacific Gas and Electric Company, 2008, PG\&E signs historic $800 \mathrm{MW}$ photovoltaic solar power agreements with OptiSolar and SunPower: Pacific Gas and Electroic Company news release, August 14, accessed June 7, 2010, at http://www.pge.com/about/news/mediarelations/ newsreleases/q3_2008/080814.shtml.

Rigley, Colin, 2009, It's kick-off time for solar: New Times, v. 23, no. 44, accessed May 12, 2009, at http://www.newtimesslo.com/news/2689/ its-kickoff-time-for-solar/.

Simons, F.S., and Prinz, W.C., 1973a, Gallium, germanium, and indium, in Brobst, D.A., and Pratt, W.P., eds.,
United States mineral resources: U.S. Geological Survey Professional Paper 820, p. 237-250, accessed June 7, 2010, at $h t t p: / / p u b s . e r . u s g s . g o v / u s g s p u b s / p p / p p 820 /$.

Simons, F.S., and Prinz, W.C., 1973b, Selenium, in Brobst, D.A., and Pratt, W.P., eds., United States mineral resources: U.S. Geological Survey Professional Paper 820, p. 573-576, accessed June 7, 2010, at http://pubs.er.usgs.gov/usgspubs/ pp/pp820/.

Simons, F.S., and Prinz, W.C., 1973c, Tellurium, in Brobst, D.A., and Pratt, W.P., eds., United States mineral resources: U.S. Geological Survey Professional Paper 820, p. 627-630, accessed June 7, 2010, at http://pubs.er.usgs.gov/usgspubs/ pp/pp820\%.

SolarThinFilms Inc., 2007, Thin-film photovoltaics: SolarThinFilms Inc., accessed May 21, 2009, at http://www.solarthinfilms.com/active/en/home/photovoltaics/ photovoltaics_and_thinfilms/thinfilm_photovoltaics.html.

Tolcin, A.C., 2009a, Cadmium, in Metals and minerals: U.S. Geological Survey Minerals Yearbook 2008, v. I, p. 15.1-15.8, accessed May 15, 2009, at http://minerals.usgs.gov/minerals/pubs/commodity/ cadmium/myb1-2008-cadmi.pdf.

Tolcin, A.C., 2009b, Indium, in Metals and minerals: U.S. Geological Survey Minerals Yearbook 2008, v. I, p. 35.1-35.8, accessed May 15, 2009, at http://minerals.usgs.gov/minerals/pubs/commodity/indium/ myb1-2008-indiu.pdf.

Tolcin, A.C., 2010a, Cadmium, in U.S. Geological Survey Mineral Commodity Summaries 2010: U.S. Geological Survey, p. 36-37, accessed June 7, 2010, at http://minerals.usgs.gov/minerals/pubs/mcs/.

Tolcin, A.C., 2010b, Indium, in U.S. Geological Survey Mineral Commodity Summaries 2010: U.S. Geological Survey, p. 74-75, accessed June 7, 2010, at http://minerals.usgs.gov/minerals/pubs/mcs/.

U.S. Department of Energy, 2010, 2008 solar technologies market report: U.S. Department of Energy, National Renewable Energy Laboratory DOE/GO-102010-2867, 119 p., accessed June 12, 2009, at http://www1.eere.energy.gov/ solar/pdfs/46025.pdf.

U.S. Department of Energy, Energy Information Administration, 2009a, Frequently asked questions-Electricity: U.S. Department of Energy, Energy Information Administration, accessed February 22, 2010, at http://tonto.eia.doe.gov/ask/ electricity_faqs.asp\#electricity_use_home.

U.S. Department of Energy, Energy Information Administration, 2009b, Electricity - U.S. data: U.S. Department of Energy, Energy Information Administration, accessed May 5, 2009, at http://www.eia.doe.gov/fuelelectric.html.

U.S. Department of Energy, Energy Information Administration, 2010, Independent statistics and analysis, Net generation by energy source-Total (all sectors): U.S. Department of Energy, Energy Information Administration, accessed 
April 22, 2010, at http://www.eia.doe.gov/cneaf/electricity/ epm/table1_1.html.

U.S. Department of Energy, National Renewable Energy Laboratory, 2000, Assessment of critical thin film resourcesTellurium: National Renewable Energy Laboratory Contract no. RAF-9-29609, 34 p., accessed May 7, 2009, at http://www.nrel.gov/pv/thin_film/docs/telluriumworldindustr ialminerals2000.doc.

U.S. Department of Energy, National Renewable Energy Laboratory, 2008, Record makes thin-film solar cell competitive with silicon efficiency: U.S. Department of Energy, National Renewable Energy Laboratory press release NR-0408, accessed June 2, 2009, at http://www.nrel.gov/ news/press/2008/574.html.

U.S. Department of Energy, Solar Technologies Program, 2008, Solar FAQs-Photovoltaics-All: U.S. Department of Energy, accessed April 1, 2009 at http://apps1.eere.energy.gov/solar/cfm/faqs/third_level.cfm/ name $=$ Photovoltaics $/$ cat $=A L L$.

U.S. Geological Survey, 2009a, Metals and minerals: U.S. Geological Survey Minerals Yearbook 2008, v. I, accessed April 12, 2009, at http://minerals.usgs.gov/minerals/pubs/ commodity/myb/.
U.S. Geological Survey, 2009b, Mineral commodity summaries 2009: U.S. Geological Survey, 195 p., accessed May 14, 2009, at http://minerals.usgs.gov/minerals/pubs/ mcs/.

U.S. Geological Survey, 2010, Mineral commodity summaries 2010: U.S. Geological Survey, 195 p., accessed April 14, 2010, at http://minerals.usgs.gov/minerals/pubs/mcs/.

Wilburn, D.R., 2007, Flow of cadmium from rechargeable batteries in the United States, 1996-2007: U.S. Geological Survey Scientific Investigations Report 2007-5198, 26 p., accessed February 4, 2010, at http://pubs.usgs.gov/ sir/2007/5198/.

Wilburn, D.R., Goonan, T.G., and Bleiwas, D.I., 2005, Technological advancement-A factor in increasing resource use: U.S. Geological Survey Open-File Report 2001-197, ver. 1.03, 81 p., accessed February 4, 2010, at http://pubs.usgs.gov/of/2001/of01-197/2001-197.pdf. 


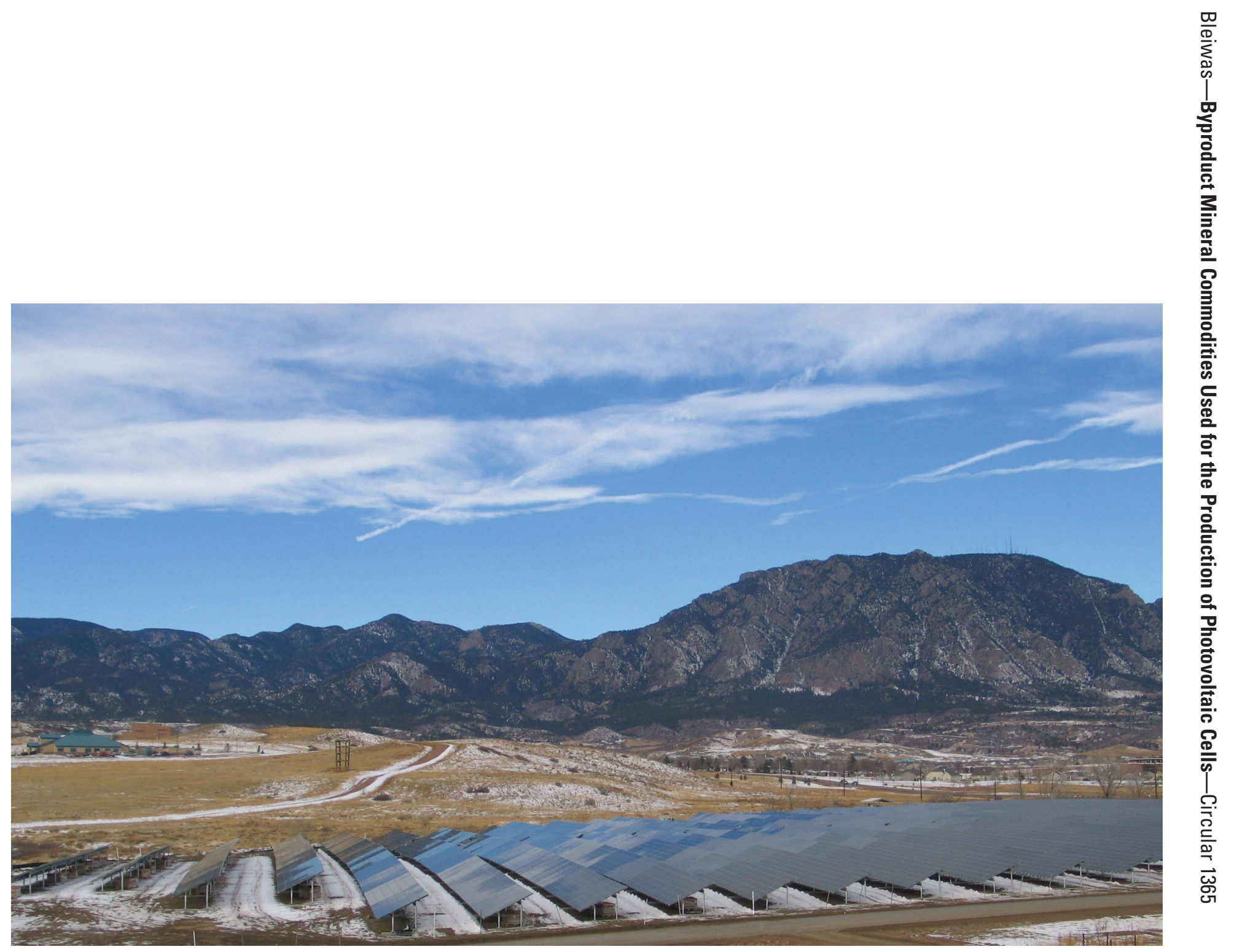

89 Printed on recycled paper 